\title{
Determinant Factors in the Formation of Students' Islamic Personality at Indonesian School of Bangkok (SIB) 2018
}

\author{
Andriyani \\ \{drandriyanimag@gmail.com\} \\ Muhammadiyah Jakarta University, Indonesia
}

\begin{abstract}
Education is a necessity for every human being. In Islam, education is evidenced by changes in attitudes and behavior in accordance with Islamic doctrine that requires activities and environment to support its success, so it can be said that Islamic education is the formation of a Muslim personality. This study was conducted at Indonesian School of Bangkok (SIB) located in Thailand with cross sectional design. The results of statistical analysis showed that students who got Islamic Education in the family environment well tend to 7,636 times have a good Islamic personality, while students who got Islamic Education in school well, tend to be 6,238 times have a good Islamic personality. Islamic education in the family environment had most significant relationship with the formation of students' Islamic personality in SIB Thailand.
\end{abstract}

Keywords : Islamic Education, School, Family Environment, Society

\section{INTRODUCTION}

Education is a necessity for every human being. Human Resources will be formed through the educational process that will play a role in the development of the nation and state[1]. Education requires the attention and participation of all related parties. It is fitting that the components in the education process such as students, teachers, teaching-learning process, management, education services and other supporting facilities must be coordinated and cooperate well[2]. Education is an activity to develop all aspects of human personality that will run for life. In general, education can also be interpreted as a human effort to foster his personality in accordance with the values in society and culture[3]. For that, Islamic qualifications for education provide clarity of conceptual form, the formation of Muslim personality and the progress of society and culture does not deviate from the Islamic doctrine[4].

In Islam, education is evidenced by changes in attitudes and behavior in accordance with Islamic doctrine that requires activities and environment to support its success, so it can be said that Islamic education is the formation of a Muslim personality[5]. Islamic personality can be seen from personality of person (individual) and personality in the society (ummah). Individual personality includes a person's characteristic in attitude and behavior, as well as his 
intellectual ability. Because of the personality of each individual, then as an individual a Muslim will display his trademark[6].

Islamic education can be obtained from the family environment, school, to the community environment where all these aspects have different roles and processes in the formation of a person's personality[7], [8]. Islamic education is an effort undertaken by a person in order to prepare human beings who can believe, understand, and practice the Islamic doctrine[9]. Based on research conducted by Nurul Fadhila (2011), implementation of Islamic education in the family environment was the most important factor for the formation of students' Islamic personality[10].

Nurul Fadhila's research was conducted in one of the schools in Indonesia, where the majority of the population is Muslim, so in applying Islamic education both in the family environment, schools, and society has not experienced significant difficulties. But when Islamic education was applied in one of the countries where Islam is a minority, it was a challenge for writers to conduct a study at one of the Indonesian Schools in Bangkok, Thailand. In addition, at this time many students who have received Islamic education but they had not formed an Islamic personality. Starting from dress, association, and others. And there are still many students who were not optimal in worship and in the society they had less reflects as an Muslim student.

\section{RESEARCH METHOD}

This study was conducted at Indonesian School of Bangkok (SIB) located in Thailand with cross sectional design. The population was all students of Junior High School and Senior High School in SIB Thailand. The sample amounted to 37 people and was selected based on the total sampling technique. The inclusion criteria in this study were stated as active students in the study period and willing to be the respondent. The dependent variable was student's islamic personality and the independent variables were Islamic Education in school, Islamic Education in family environment, and Islamic Education in society. Data collected includes data on Islamic Education in school, Islamic Education in the family environment, and Islamic Education in society. Other data collected were data of individual characteristics in the form of age and gender.

\section{RESULT AND DISCUSSION}

The distribution result of the student's islamic personality showed the proportion of students who had less Islamic personality were 18 people $(48,6 \%)$ and students who had good Islamic personality were 19 people $(51,4 \%)$.

Table 1. Proportion of Respondents based on Islamic Personality

\begin{tabular}{|l|c|c|}
\hline Islamic Personality & n & \% \\
\hline Less & 18 & 48,6 \\
\hline Good & 19 & 51,4 \\
\hline Total & 37 & 100 \\
\hline
\end{tabular}

Table 2 was the result of bivariate analysis on the relationship of student characteristic towards the formation of students' Islamic personality. The results of the analysis indicate that age and sex were not related to the formation of students' Islamic personality. This was 
evidenced by the value of $\mathrm{p}$ value at age and gender more than $0.05(\mathrm{p}>0.05)$ that is 0.223 and 0.325 , whereas Islamic Education in schools, Islamic Education in the family environment and Islamic Education in the society had a significant relationship.

In the variable of Islamic Education in school, students who got Islamic Education in school well tend to be 4.4 times as likely to have a good Islamic personality (OR = 4,400; $95 \% \mathrm{CI}=1.093$ - 17,720). Students who got Islamic Education in the family environment well tend to be 5,333 times bigger have good Islamic personality $(\mathrm{OR}=5,333 ; 95 \% \mathrm{CI}=1,142$ 24,899). In the variable of Islamic Education in the society, students who got Islamic Education in the community well tend to be 4,688 times have a good Islamic personality (OR $=4,688 ; 95 \% \mathrm{CI}=1,108-19,834)$.

Of the five variables studied, only variable Islamic Education at school, Islamic Education in the family environment and Islamic Education in society had a p value less than 0.05 ( $p$ value $<0.05$ ), so only those variables were included in multiple logistic analyzes. The result of multiple logistic test shown in Table 3 was obtained 2 dominant variable that were Islamic Education in school and Islamic Education in family environment. The results of statistical analysis showed that students who got Islamic Education in the family environment well tend to 7,636 times have a good Islamic personality $(\mathrm{OR}=7,636 ; 95 \% \mathrm{CI}=1,330-43,850)$, while students who got Islamic Education in school well, tend to be 6,238 times have a good Islamic personality $(\mathrm{OR}=6,238 ; 95 \% \mathrm{CI}=1,253$ - 31,062) compared with students who lacked Islamic Education at school.

Table 2. Correlation Between Student Characteristics and Islamic Education towards the Formation of Students' Islamic Personality in SIB 2018

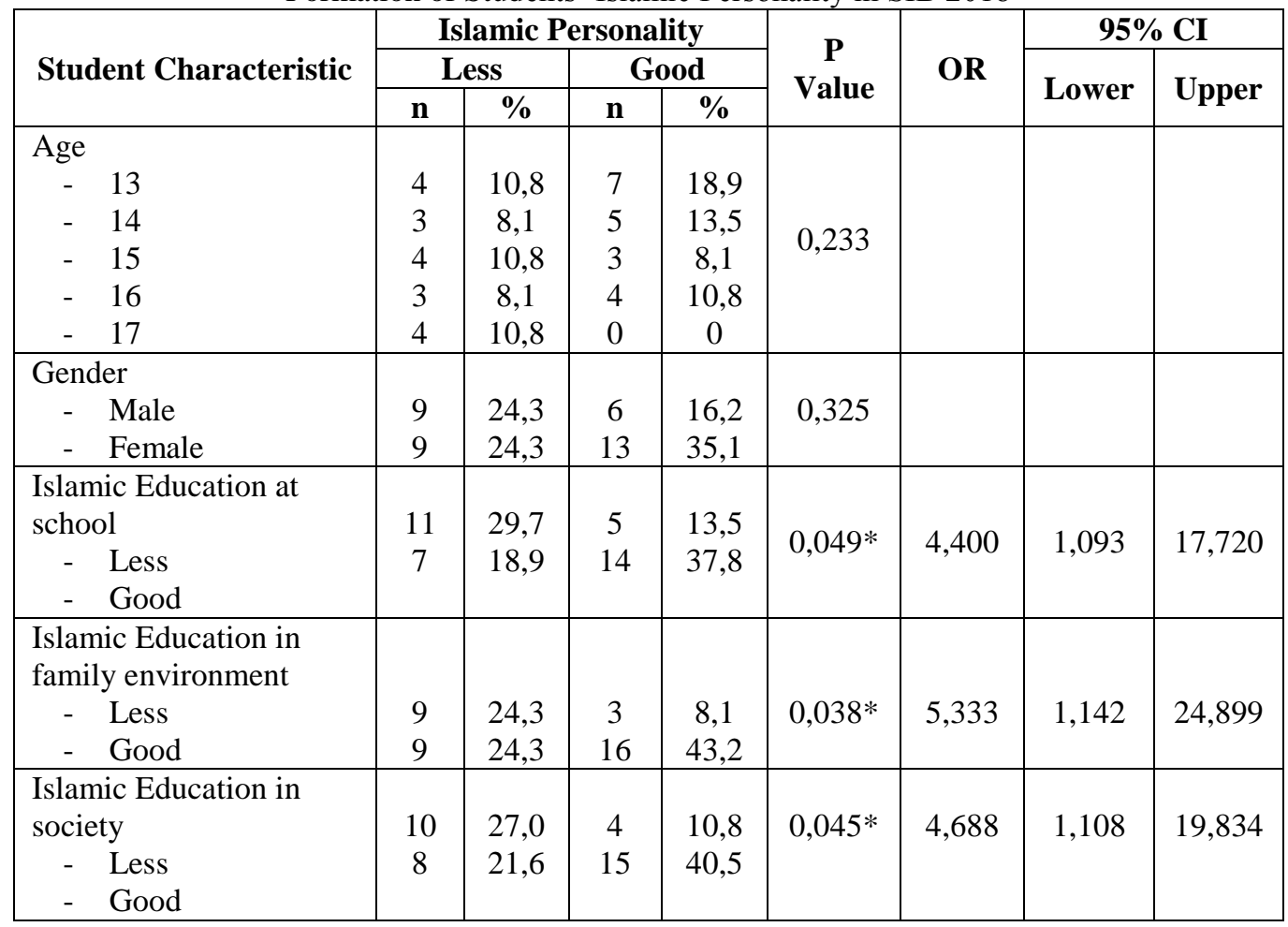


Table 3. Multivariate Analysis of Sudents' Islamic Personality

\begin{tabular}{|l|c|c|c|c|c|c|}
\hline \multicolumn{1}{|c|}{ Variable } & \multirow{2}{*}{ B } & \multirow{2}{*}{ Wald } & \multirow{2}{*}{$\boldsymbol{P}$ Value } & \multirow{2}{*}{ OR } & \multicolumn{2}{c|}{ 95\% CI } \\
\cline { 6 - 8 } & & & Lower & Upper \\
\hline Islamic Education at school & 1,831 & 4,966 & 0,025 & 6,238 & 1,253 & 31,062 \\
\hline $\begin{array}{l}\text { Islamic Education in family } \\
\text { environment }\end{array}$ & 2,033 & 5,195 & 0,023 & 7,636 & 1,330 & 43,850 \\
\hline Constant & $-2,373$ & 6,040 & 0,014 & 0,093 & & \\
\hline
\end{tabular}

Based on bivariate results, the proportion of students who had good personality was more prevalent in students with age 13 years and in female students. This was because 13 years old students had not much social with the outside world such as students with age above. It is as revealed by Dafiq (2012) that the development of personality is basically individual, but in fact the personality was apparently can be transmitted or affect others. When a teenager started hanging out with his or her negative personality such as: lazy, violating rules / discipline, apathy and lying, he or she will likely become a negative character. Therefore it was necessary to know about the methods of personality formation of children that can be used as a guide by parents and teachers as early childhood educators to be able to form a child who has a positive personality traits and ready to face the challenges of the future[11]. However, the results showed that there was no significant correlation between age and gender with the formation of students' Islamic personality ( $p$ value $>0.05$ ).

In table 2, it could be seen that the proportion of students who had a good personality was more in the students who got Islamic education in school, family environment, and society well than the students who were lack of Islamic education both in school, family environment, and society. This result stated that there was a significant relationship between Islamic education in the schools with the formation of students' Islamic personality ( $\mathrm{p}$ value $<0,05$ ). Students who were well educated in schools tend to be 4.4 times as likely to have a good Islamic personality $(\mathrm{OR}=4,400 ; 95 \% \mathrm{CI}=1,093-17,720)$.

This accordance with the study conducted by Eliana Sari (2014) stated that if the management of Islamic education in the school environment was improved, the effectiveness of the application of one percent of students' emotional intelligence will increase by $0.907 \%$. Management of Islamic education in the school environment could actually be a major solution of the education system in the school environment as preventive and anticipatory to the deviant behavior of students. Efforts to foster religious behavior in the management of Islamic education in the school environment could be done in the form of celebrating religious holidays, providing worship facilities for the entire school community and to provide opportunities for the entire school community[5].

This was also accordance with a case study conducted by Diallo (2016) in Australia that found Islamic studies in Islamic community schools aimed at developing and maintaining Muslim student identity by teaching them Islamic culture and faith while at the same time trying to create opportunities for students to engage with the social, cultural and political issues facing Muslim communities in Australia and elsewhere. Muslim students had the opportunity to discuss Islamic teachings and values with their peers, their teachers, priests, or community leaders on issues affecting them personally and communities[12]. Islam in a minority country had some similarities especially in the application of Islamic education in the schools[13], it was also occured in the Indonesian Schools of Bangkok, Thailand.

Islamic education in the family environment also had a significant relationship with the formation of students' Islamic personality in SIB Thailand ( $p$ value $<0.05$ ). Students who get Islamic education in the family environment tend to be 5,333 times bigger have good Islamic 
personality $(\mathrm{OR}=5,333 ; 95 \% \mathrm{CI}=1,142-24,899)$. According to Muhammad and Rafikul (2011) in his research, strong Islamic values infused in a family could help the student's in the formation of Islamic personality and able to transform them into a good Muslims[14]. This was in line with research conducted by Adamu et al (2015) which revealed a strong positive correlation between parental involvement and the performance of Islamic Education. He stated that the increased involvement of parents was significantly related to improvements in student learning performance in Islamic Education[15].

This was also accordance with the Holy Qur'an in At-Tahrim (66) verse 6 :

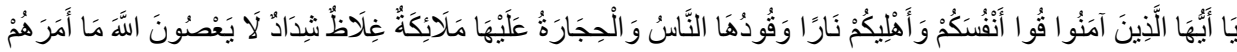

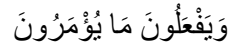

Which means :

O you who have believed, protect yourselves and your families from a Fire whose fuel is people and stones, over which are [appointed] angels, harsh and severe; they do not disobey Allah in what He commands them but do what they are commanded.

Islamic Education in the society had a significant correlation with the formation of students' Islamic personality. Students who got Islamic Education in the community well tend to be 4,688 times have a good Islamic personality $(\mathrm{OR}=4,688 ; 95 \% \mathrm{CI}=1,108-19,834)$. As stated by Institute of Medicine, National Research Council (2011) in their workshop report, at this time teenagers spend most of their time outdoors with their peers, so it can be understood if peers were very influential on the attitude, manner of talk, interest, appearance, and behavior of adolescents. Social change was evident in changes in attitudes and behaviors, which could constitute harsh obstacles and challenges to changes in religious and moral attitudes and behavior[16].

\section{CONCLUSIONS}

Based on multivariate analysis, Islamic education in the family environment had most significant relationship with the formation of students' Islamic personality in SIB Thailand ( $p$ value $<0.05$ ). Students who get Islamic education in the family environment tend to be 5,333 times bigger have good Islamic personality ( $\mathrm{OR}=5,333 ; 95 \% \mathrm{CI}=1,142$ - 24,899).

\section{REFERENCES}

[1] A. Bhardwaj, "Importance of Education in Human Life : a Holistic Approach," Int. J. Sci. Conscious., vol. 2, no. 2, pp. 23-28, 2016.

[2] S. E. Lee, "Education as a Human Right in the 21st Century.," Democr. Educ., vol. 21, no. 1, pp. 1-9, 2013.

[3] Unicef, A Human Rights-Based Approach to Education for All. New York: United Nations Children's Fund, 2007.

[4] M. R. Kroessin, "Religions and Development Research Programme Concepts of Development in 'Islam ': A Review of Contemporary Literature and Practice," Birmingham, 2008.

[5] E. Sari, "The Relation Between Islamic Education Environment Management and Student Emotional Intelligence,” Int. J. Nusant. Islam, vol. 1, no. 2, pp. 206-222, 2014.

[6] R. Smither and A. Khorsandi, "The Implicit Personality Theory of Islam," Psycholog. 
Relig. Spiritual., vol. 1, no. 2, pp. 81-96, 2009.

[7] E. Nurjanah, "Modernization Of Islamic Education In The Rural Family," vol. 2, no. 1, pp. 1-5, 2013.

[8] R. K. Hayah, "Character Education in Islamic Boarding School and The Implication to Students' Attitude and Critical Thinking Skills on Biodiversity Learning," J. Phys. Conf. Ser., vol. 9, no. 1, pp. 3-10, 2017.

[9] B. I. Anshari, M. Yutika, M. Dede, and R. E. Rahayu, "Islamic Education Learning Design Based on Sistem Among," in Islamic Education Faces Global Challenges, 2016, pp. 105-114.

[10] N. Fadhilah, "Hubungan Pendidikan Agama Islam dengan Kepribadian Islami Siswa SMPN 90 Jakarta Timur," UIN Syarif Hidayatullah Jakarta, 2011.

[11] D. Chairilsyah, "Pembentukan Kepribadian Positif Anak Sejak Usia Dini," Educhild, vol. 1, no. 1, pp. 1-7, 2012.

[12] I. Diallo, "The Role and Importance of Islamic Studies and Faith in Community Islamic Schools in Australia," Res. Cent. Laanguages Cult., no. October, 2016.

[13] S. Thobani, "The Dilemma of Islam as School Knowledge in Muslim Education," Asia Pacific J. Educ., vol. 27, no. 1, pp. 11-25, 2007.

[14] M. K. Islam and R. Islam, "Strengthening Muslim family institution: A management perspective,” Pertanika J. Sci. Technol., vol. 19, no. 1, pp. 81-97, 2011.

[15] A. Z. Ubale and A. H. Abdullah, "A Correlation Study Of Parental Involvement And Islamic Education' $\mathrm{s}$ Achievment Among Smka Students In Kuala Terengganu Malaysia,” Int. J. Acad. Res. Bus. Soc. Sci., vol. 5, no. 10, pp. 30-44, 2015.

[16] Institute of Medicine and National Research Council, The Science of Adolescent RiskTaking. Washington D.C.: The National Academy Press, 2011. 